\title{
Isolation of Azoreductase Enzyme in Its Various Forms from Chlorella pyrenoidosa and Its Immobilization Efficiency for Treatment of Water
}

\author{
J. Thirumagal ${ }^{1}$, A. Panneerselvam ${ }^{2}$ \\ ${ }^{1}$ Research Scholar, Department of Zoology, Thiruvalluvar University, Vellore, Tamil Nadu, India \\ ${ }^{2}$ Associate Professor, Department of Zoology, Thiruvalluvar University, Vellore, Tamil Nadu, India
}

\begin{abstract}
Azo dyes are very common toxic substances which are now a days been ejected out from many textile industries and mixed in the lake water. The negative side of azo dyes is their aesthetic effects and their biotransformation which are toxic to aquatic life and also causes mutagenecity to living organisms. Azo dyes are quite difficult to destroy and decompose by common treatments. The application of algae and its enzymes have been proving in the field of waste water decolorization and degradation. In this study, the enzymatic activity of the Chlorella pyrenoidosa had been studied and isolation of enzyme in intracellular and extracellular forms was done for the molecular weight determination by SDS-PAGE method. It was noted that the enzyme molecular weight was higher in intracellular form of about approximately 30KDa and 19KDa in extracellular form. Protein content in the enzymes were analyzed and recorded the higher protein content of $105 \mathrm{mg}$ in intracellular form of the enzyme which confirms the degradation ability of Chlorella pyrenoidosa by its secretion of enzymes. The immobilization efficiency of the dye was also observed using sodium alginate as complex and found that as the concentration of dye increased, immobilization efficiency also increased, maximum was observed in the Intracellular enzyme form of about $79.9 \%$ for which the kinetics were also measured.
\end{abstract}

Keywords: Azodyes, Chlorella pyrenoiosa, degradation, Enzymes, SDS-PAGE, Protein

\section{Introduction}

Azodyes from the textile industries are the stable compounds whose little quantity in water is highly visible and tend to alter the water properties making it unfit for use. Many researchers have studied the effect of algae and enzymes on decolorization characteristics since immobilization provide distinct stability over free cells. Algae have been studied in the field of decolorization of industrial effluent [6].

\section{Azoreductases}

This enzyme belongs to the family of oxidoreductases, specifically those acting on other nitrogenous compounds as donors with NAD+ or NADP+ as acceptor [7]. The reductive cleavage of the azo bond catalyzed by the azoreductase, the key enzyme of azo dye degradation [9].

\section{Treatment of dyes}

Physical and chemical treatments of dye are very common which includes precipitation, coagulation, adsorption, flocculation, flotation, electrochemical destruction, and mineralization. These processes are disadvantageous as cost, time, and release of residues are high. These methods help in minimizing the level of toxicity and do not neutralize it [7]. As an alternative to these techniques, microorganism can be used to degrade the dyes completely, as microorganisms have the capability to secrete enzymes which can be employed to reduce the dyes toxicity [4]. Biological treatment for dye elimination is based on microbial biotransformation of dyes. The compact forms of dye structure are destroyed to simpler compounds and are utilized as energy source by microbes [10].
Role of algae in degradation of dye

Algae can play an important role in the removal of azo dyes and aromatic amines. Algae are potential biosorbents because of their easy growth in water. Biosorption by algae is possible because of the cell wall properties of algae, electrostatic attraction [8]. Functional groups such as hydroxyl, carboxylate, amino and phosphate found on the algal cell surface which play a prominent role during sequestration of contaminants from wastewater. Some species of algae were capable of utilizing azo dyes as their sole source of carbon and nitrogen for its growth [5].

Possibility of decolorisation by algae is due to the efficient utilizationofchromophores from dye for production of algal biomass and its tendency to absorb the utilized chromophores on its biomass, $\mathrm{CO}_{2}$ and $\mathrm{H}_{2} \mathrm{O}$ transformation of coloured molecules to non-colored molecules [3].

\section{Materials and Methods}

Source of organism

The Chlorella pyrenoidosa was collected from Genewin Biotech, Hosur and further grown in its medium.

\section{Growth of Chlorella pyrenoidosa}

The Chlorella pyrenoidosa was initially grown in the specific medium; Fog's medium and expanded for its mass multiplication.

\section{Expansion of Chlorella pyrenoidosa}

The Chlorella pyrenoidosa which were cultivated was grown and then expanded in the 25 litres Bubble tops in 


\section{International Journal of Science and Research (IJSR) \\ ISSN (Online): 2319-7064}

Index Copernicus Value (2013): 6.14 | Impact Factor (2015): 6.391

order to get the huge production of algae. The medium used for the growth of Chlorella pyrenoidosa was Fog's medium. The Chlorella pyrenoidosa were grown in the Bubble tops and the algal biomass was collected.

\section{Isolation of enzymes \\ Extracellular enzyme preparation}

Extracellular part of the enzyme collection was done after Chlorella pyrenoidosa growth in the dye for about 10 days; the culture contained the azo dye concentration of 50 ppm. After its growth, the culture was centrifuged at 5000 rpm for $20 \mathrm{~min}$. The supernatant solution was collected and used for Extracellular enzyme activity studies [10].

\section{Intracellular enzyme preparation}

Intracellular part of the enzyme was collected by centrifuging the culture holding the dye concentration of $50 \mathrm{ppm}$ along with Chlorella pyrenoidosa after its growth in the dye for about 10 days at $5000 \mathrm{rpm}$ for $10 \mathrm{~min}$ [11]. The pellet was collected and washed with the phosphate buffer and resuspended in the same buffer. The suspended enzyme was sonicated to break the cell wall and debris for $10 \mathrm{~min}$ at $20 \mathrm{kHz}$. The sonicated enzyme solution was again centrifuged at $5000 \mathrm{rpm}$ for $15 \mathrm{~min}$ to remove all unbroken cells. The supernatant was removed and used for the Intracellular enzyme studies [10].

\section{Azoreductase activity from intra and extra cellular enzyme}

Assay for azoreductase activity was performed using the following materials:

1. Potassium phosphate buffer 50mM (Reagent A)

2. Azo dye solution $0.1 \%$, (Reagent B)

3. Enzyme solution (Reagent C)

4. Reduced nicotinamide adenine dinucleotide sodium salt monohydrate (NADH) $2 \mathrm{mM}$ (Reagent D)

The assay procedure is based on the principle that with the addition of $\mathrm{NADH}$ to the reaction mixture containing substrate, buffer and enzyme solution, the substrate azo dyes azo bond is degraded and there is a decrease in the absorbance of the dye after an initial lag phase. Unit Definition: One unit will reduce 1. $0 \mu$ mole of azo dye per minute in the presence of $\mathrm{NADH}$ using Millimolar extinction coefficient of azo dye at $\mathrm{pH} 7.0$ and $30^{\circ} \mathrm{C}$ temperature.

The procedure adopted was based on the one done by Zimmermann et al. (1982).

1. Pipetted (in milliliters) the following reagents into test tubes:

Test Blank

Reagent A (Buffer) 2.802 .80

Reagent B (Azo dye solution) 0.050 .05

Reagent C (Enzyme solution) 0.1 0.1(Distilled water)

Mixed by inversion and equilibrate at room temperature.

Then add:
Reagent D (NADH) 0.050 .05

2. Immediately mixed by inversion and recorded the decrease in absorbance at $532 \mathrm{~nm}$ for approximately 5 min. obtained the $\Delta \mathrm{A} 532 \mathrm{~nm} /$ minute for both the Test and Blank.

\section{Calculation}

Units $/ \mathrm{ml}$ enzyme $=\mathrm{A} 532 \mathrm{~nm} / \min$ Test $-\Delta \mathrm{A} 532 \mathrm{~nm} / \mathrm{min}$ Blank) (3) (df)

$(\Delta \mathrm{B} \times(0.1)$

$3=$ Total volume (in milliliters) of assay; $\mathrm{df}=$ Dilution factor (1); $\mathrm{B}=$ Millimolar extinction coefficient of azo dye Malachite green $\left(1.5 \times 10^{5}\right) ; 0.1=$ Volume (in milliliter) of enzyme used.

\section{Enzyme Purification}

The collected enzymes were partially purified using Ammonium sulphate precipitation method. The intra and extracellular enzymes were added with ammonium sulfate until it was $30-35 \%$ saturated and the solution was vortexed for $10 \mathrm{~min}$. The pellet was collected after the centrifugation and again resuspended in $10 \mathrm{ml}$ of $0.1 \mathrm{M}$ phosphate buffer ( $\mathrm{pH} 7$ ). The obtained precipitate is stored at $4{ }^{\circ} \mathrm{C}$ for its molecular weight determination [5]

\section{Molecular weight determination of enzymes}

The precipitated enzyme was allowed to run on the SDSPAGE Electrophoresis which when running on the resolving gel of $12 \%$ and stacking gel of $4 \%$ given the molecular weight of the precipitated intra and extracellular enzymes [2].

\section{Stock acrylamide-bisacrylamide}

It was prepared by dissolving $30.0 \mathrm{~g}$ of acrylamide and 0.8 $\mathrm{g}$ of bisacrylamidein $70 \mathrm{~mL}$ of deionised water and made upto $100 \mathrm{mlsolution}$ was filtered.

\section{Resolving gel buffer (1.5 M TrisHCl)}

In a $100 \mathrm{ml}$ volumetric flask, $18.2 \mathrm{~g}$ of Tris base was dissolved in $70 \mathrm{~mL}$ of deionised water and made up to 100 $\mathrm{ml}, \mathrm{pH}$ was adjusted to 8.8 stored at $4{ }^{\circ} \mathrm{C}$.

\section{Stacking gel buffer (0.5 M TrisHCl)}

In a $100 \mathrm{ml}$ volumetric flask, $6.1 \mathrm{~g}$ of Tris base was dissolved in $70 \mathrm{~mL}$ of deionised water and made up to 100 $\mathrm{mL}$ with deionised water, $\mathrm{pH}$ was adjusted to 6.8; preserved at $4{ }^{\circ} \mathrm{C}$.

\section{$10 \%$ SDS solution}

$10 \mathrm{~g}$ of SDS was dissolved in $100 \mathrm{~mL}$ of deionised water and stored at room temperature. 


\section{International Journal of Science and Research (IJSR) \\ ISSN (Online): 2319-7064}

Index Copernicus Value (2013): 6.14 | Impact Factor (2015): 6.391

\section{Electrode buffer (5 X)}

$5 \mathrm{X}$ electrode buffer consisted of $15 \mathrm{~g}$ of Tris base, $72 \mathrm{~g}$ glycine and $5 \mathrm{~g}$ SDS were dissolved in 1 litre of deionised water and stored in a clean glass container. One part of this with four parts water was used for the analysis. The $\mathrm{pH}$ of the buffer was 8.3 before use.

\section{Sample preparation}

Equal volumes of the sample was mixed and heated for five minutes and cooled at room temperature.

\section{Electrophoresis Unit}

The samples were loaded into the well with the help of micro pipette once the gel had been casted. The marker of $1 \mathrm{~Kb}$ ladder was loaded. Then SDS-PAGE unit was connected with voltage supplier. The lower electrode chamber was connected to the anode and the upper one to the cathode. Finally, $100 \mathrm{~V}$ of current was applied and allowed to run until the bromophenol tracking dye reached the bottom of the resolving gel.

\section{UV Trans illuminator}

The molecular weight was calculated from the visualized sample bands using UV trans illuminator. It was determined by comparing the visualized bands with the molecular weight of the marker. $1 \mathrm{~Kb}$ ladder was chosen for the study.

\section{Protein assay}

Protein was determined from the intra and extracellular enzyme samples by the method of Lowry et al (1951) and values were tabulated [10].

Immobilization of the isolated enzymes using sodium alginate as complex

Azoreductase enzyme (EC 1. 7.1. 6) was preceded with the process of Immobilization by method of alginate bead using entrapment method. $2.5 \%$ sodium alginate and $0.2 \mathrm{M}$ $\mathrm{CaCl}_{2}$ was prepared separately. Equal volume of sodium alginate and isolated azoreductase enzyme was mixed and beads were prepared. Mixture was dropped into prepared $0.2 \mathrm{M}$ calcium chloride and was incubated overnight in stirring condition using magnetic stirrer [15].

\section{Effect of dye concentration and enzyme dose}

The dye concentration and enzyme dose was varied from $10,20,30,40,50 \mathrm{ppm}$ respectively and $1018 \mathrm{IU}$ as intracellular enzyme, $210 \mathrm{IU}$ as extracellular enzyme respectively in the reaction mixture.

\section{Determination of enzyme kinetics (Kmand Vmax)}

Enzyme kinetics is one of the most common function to relate enzyme activity (v) to substrate concentration $(C)$ is the Michaelis-Menten equation [16]

$\mathrm{V}=\mathrm{V}_{\max } \mathrm{C} / \mathrm{K}_{\mathrm{m}}+\mathrm{C} \times \mathrm{M}$ where $\mathrm{v}(\mathrm{mg} \mathrm{h}-1)$ is the degradation rate of the substrate concentration $\mathrm{C}(\mathrm{mg} \mathrm{L}-1), \mathrm{Vmax}(\mathrm{mg} \mathrm{kg}-1 \mathrm{~h}-1)$ is the maximal degradation velocity, $\mathrm{Km}(\mathrm{mg} \mathrm{L}-1)$ is the halfsaturation constant (the substrate concentration where the disappearance velocity is half the maximum). Linear equation is $1 / \mathrm{v}$ and $1 / \mathrm{C}$. The slope of the line is $\mathrm{Km} / \mathrm{Vmax}$, the $1 / \mathrm{v}$ intercept is $1 / \mathrm{Vmax}$.

\section{Results and Discussion}

\section{Growth of Chlorella pyrenoidosa}

Table 1: Growth curve of Chlorella pyrenoidosa

\begin{tabular}{|c|c|}
\hline Days & OD $(660 \mathbf{~ n m})$ \\
\hline 1 & 0.0726 \\
\hline 2 & 0.0989 \\
\hline 3 & 0.1357 \\
\hline 5 & 0.3602 \\
\hline 6 & 0.5774 \\
\hline 7 & 0.7199 \\
\hline 8 & 0.8568 \\
\hline 9 & 0.9261 \\
\hline 10 & 1.043 \\
\hline & \\
\hline
\end{tabular}

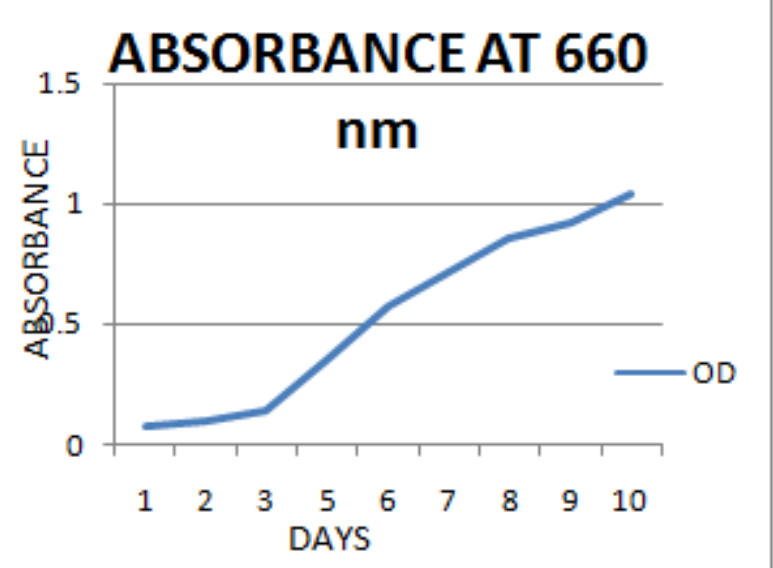

Graph 1: Graph showing the Growth curve of Chorella pyrenoidosa

The growth was recorded for 10 days and found the constant increase in its absorbance proving its living nature. The optimum light and oxygen were given for its growth at room temperature.

\section{Expansion of Chlorella pyrenidosa}

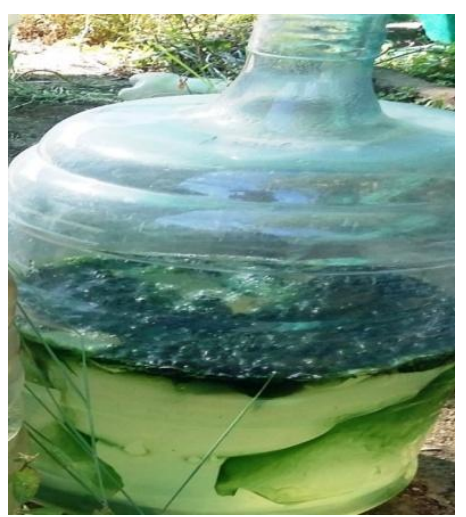

Figure 1: Expansion of Chlorella pyrenoidosa in a bubble top 


\section{International Journal of Science and Research (IJSR) \\ ISSN (Online): 2319-7064}

Index Copernicus Value (2013): 6.14 | Impact Factor (2015): 6.391

Chlorella pyrenoidosa was expanded in a 201 bubbletop and the growth was confirmed by its dark green color growth. Multiplication taken place for about 15 days.

\section{azoreductase activity in dye by Chlorella pyrenoidosa}

Table 2: Azoreductase activity in dye at $50 \mathrm{ppm}$

\begin{tabular}{|c|c|c|c|}
\hline $\begin{array}{c}\text { Time } \\
(\mathbf{s})\end{array}$ & $\begin{array}{c}\text { Absorbance } \\
\text { of Blank at } \\
\mathbf{5 3 2} \mathbf{~ n m}\end{array}$ & $\begin{array}{c}\text { Absorbance of } \\
\text { Intracellular } \\
\text { Enzyme at 532 } \\
\mathbf{n m}\end{array}$ & $\begin{array}{c}\text { Absorbance of } \\
\text { Extracellular } \\
\text { Enzyme at 532 } \\
\mathbf{n m}\end{array}$ \\
\hline 10 & 0.0256 & 0.0979 & 0.02549 \\
\hline 20 & 0.0250 & 0.0981 & 0.0247 \\
\hline 30 & 0.0247 & 0.0944 & 0.0242 \\
\hline 40 & 0.0254 & 0.0941 & 0.0254 \\
\hline 50 & 0.0251 & 0.0943 & 0.0267 \\
\hline 60 & 0.0279 & 0.0944 & 0.0267 \\
\hline 70 & 0.0262 & 0.0928 & 0.0259 \\
\hline 80 & 0.0252 & 0.0926 & 0.0249 \\
\hline 90 & 0.0266 & 0.0910 & 0.0251 \\
\hline 100 & 0.0245 & 0.0912 & 0.0263 \\
\hline 110 & 0.0222 & 0.0909 & 0.0260 \\
\hline 120 & 0.0101 & 0.0896 & 0.0265 \\
\hline
\end{tabular}

Intracellular enzyme activity at $50 \mathrm{ppm}$ dye $=1590$ molar units $/ \mathrm{ml}$ enzyme $=1.590$ millimolarunits/ $\mathrm{ml}$ enzyme $=$ 1018 IU

Extracellular enzyme activity at $50 \mathrm{ppm}$ dye $=328$ molar units $/ \mathrm{ml}$ enzyme $=0.328$ millimolarunits $/ \mathrm{ml}$ enzyme $=$ $210 \mathrm{IU}$

The enzyme activity was performed in Chlorellapyrenoidosa at dye concentration of $50 \mathrm{ppm}$. Optimized enzyme release was found by Chlorella pyrenoidosa. The highest enzyme activity was found at 50 ppm in intracellular of about 1590 molar units/ml enzyme than in extracellular of 0.328 millimolar units $/ \mathrm{ml}$ enzyme.

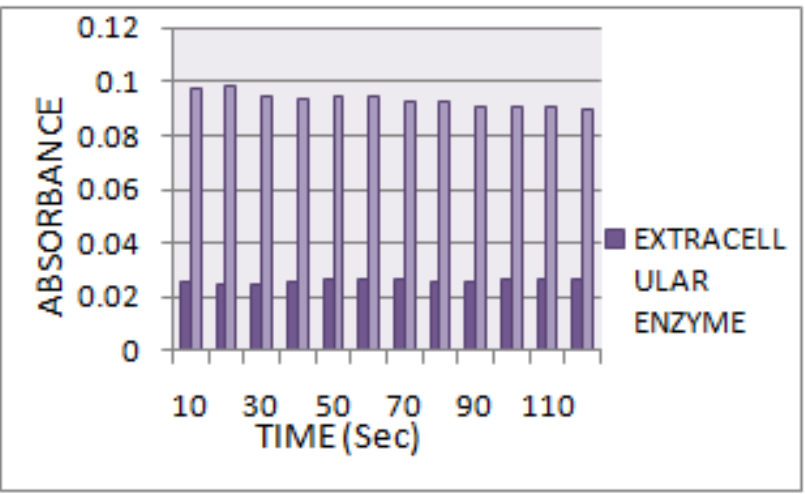

Graph 2: Graph showing the Azoreductase enzyme activity in Extracellular and Intracellular activity

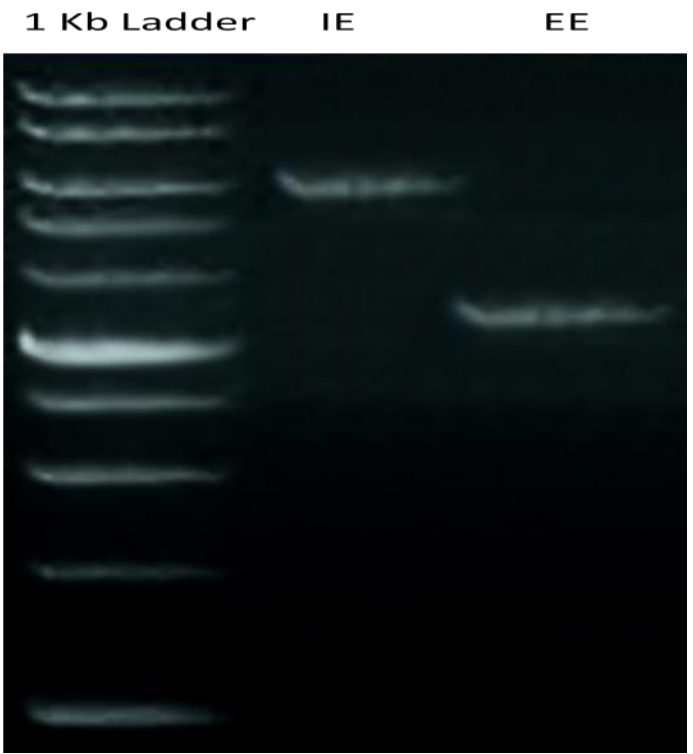

Figure 2: Molecular weight determination of purified enzymes

Key: EE- Extracellular enzyme molecular weight determination

IE - Intracellular enzyme molecular weight determination

The molecular weight of azoreductase enzyme in 2 forms determined by SDS PAGE under the experimental conditions was found as $\sim 30 \mathrm{kDa}$ and $\sim 19 \mathrm{kDa}$ for intracellular and extracellular forms respectively.

\section{Protein assay}

The intracellular and extracellular enzymes isolated were estimated for the protein content by Lowry method.

Table 3: Protein Estimation in Enzymes

\begin{tabular}{|c|c|}
\hline Sample & Estimation of Proteins (mg/ml) \\
\hline Intracellular enzyme protein & 105 \\
\hline Extracellular enzyme protein & 87 \\
\hline
\end{tabular}

The protein content was higher in the intracellular form of enzyme of about $105 \mathrm{mg} / \mathrm{ml}$ and was found to have little lower protein content for Extracellular form of enzyme of about $87 \mathrm{mg} / \mathrm{ml}$.

Enzyme activity in decolorisation after immobilization

Table 4: Intracellular enzyme activity

\begin{tabular}{|c|c|c|c|}
\hline \multirow{4}{*}{$\begin{array}{c}\text { MATRI } \\
\mathbf{X}\end{array}$} & $\begin{array}{c}\text { INTRACELLUL } \\
\text { AR ENZYME }- \\
\text { DYE } \\
\text { CONCENTRATI } \\
\text { ON (ppm) }\end{array}$ & $\begin{array}{c}\text { ENZYM } \\
\mathbf{E} \\
\text { ACTIVIT } \\
\text { Y (IU/g } \\
\text { matrix) }\end{array}$ & $\begin{array}{c}\text { IMMOBILIZATI } \\
\text { ON } \\
\text { EFFFICIENCY }\end{array}$ \\
\hline \multirow{4}{*}{$\begin{array}{c}\text { Sodium } \\
\text { alginate } \\
\text { complex }\end{array}$} & 10 & 1032 & 62 \\
\cline { 2 - 4 } & 20 & 1089 & 67.3 \\
\cline { 2 - 4 } & 30 & 1094 & 70.2 \\
\cline { 2 - 4 } & 40 & 1112 & 76.5 \\
\hline
\end{tabular}




\section{International Journal of Science and Research (IJSR) \\ ISSN (Online): 2319-7064}

Index Copernicus Value (2013): 6.14 | Impact Factor (2015): 6.391

Table 5: Extracellular enzyme activity

\begin{tabular}{|c|c|c|c|}
\hline \multirow{2}{*}{ ENZYME } & \multicolumn{3}{|c|}{ LINE - WEAVER BURK PLOT } \\
\cline { 2 - 4 } & $\begin{array}{c}\mathbf{V}_{\mathbf{m a x}} \mathbf{( \mathbf { m g ~ K g } ^ { \mathbf { 1 } }} \\
\left.\mathbf{h}^{\mathbf{1}}\right)\end{array}$ & $\left.\mathbf{K}_{\mathbf{m}} \mathbf{( m g h}^{\mathbf{- 1}}\right)$ & $\mathbf{R}^{\mathbf{2}}$ \\
\hline Intracellular & 108.44 & 12.33 & 0.9765 \\
\hline Extracellular & 33.12 & 7.41 & 0.9467 \\
\hline
\end{tabular}

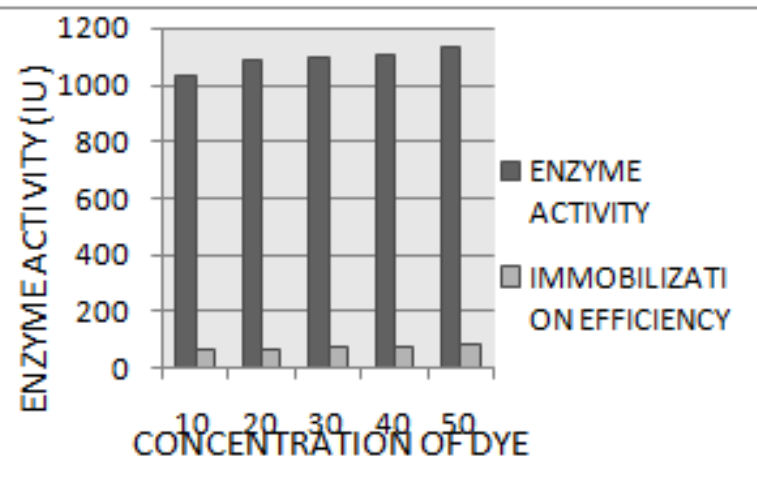

Graph 3: Graph showing the Immobilization efficiency and enzyme activity in Intracellular enzyme

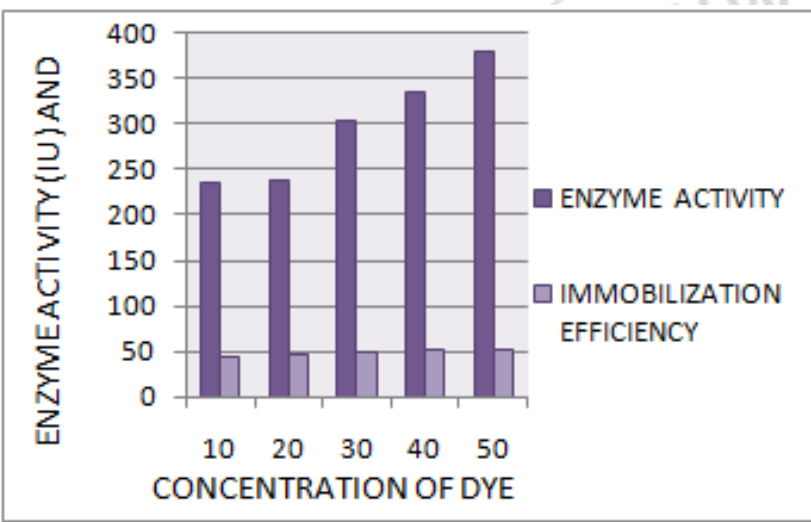

Graph 4: Graph showing the Immobilization efficiency and enzyme activity in Extracellular enzyme

Kinetics in the isolated enzymes

Table 6: Kinetics for the Isolated enzymes

\begin{tabular}{|c|c|c|c|}
\hline \multirow{4}{*}{$\begin{array}{c}\text { MATRI } \\
\mathbf{X}\end{array}$} & $\begin{array}{c}\text { EXTRACELLUL } \\
\text { AR ENZYME } \\
\text { DYE } \\
\text { CONCENTRATI } \\
\text { ON (ppm) }\end{array}$ & $\begin{array}{c}\text { ENZYM } \\
\mathbf{E} \\
\text { ACTIVI } \\
\text { TY (IU/g } \\
\text { matrix) }\end{array}$ & $\begin{array}{c}\text { IMMOBILIZATI } \\
\text { ON }\end{array}$ \\
\hline \multirow{3}{*}{$\begin{array}{c}\text { Sodium } \\
\text { alginate } \\
\text { complex }\end{array}$} & 10 & 236 & 45.6 \\
\cline { 2 - 4 } & 20 & 239 & 47.2 \\
\cline { 2 - 4 } & 30 & 304 & 49.3 \\
\cline { 2 - 4 } & 40 & 334 & 51.6 \\
\hline
\end{tabular}

\section{Discussion}

The azoreductase activity was assessed at $\mathrm{pH}-5, \mathrm{pH}-6$, $\mathrm{pH}-7, \mathrm{pH}-8$ and $\mathrm{pH}-9$.Maximum azoreductase activity was recorded by the bacterial consortium at $\mathrm{pH}-7$ (9.641 $\mathrm{U} / \mathrm{ml})$ followed by $\mathrm{pH}-6(7.561 \mathrm{U} / \mathrm{ml}), \mathrm{pH}-5(6.770$ $\mathrm{U} / \mathrm{ml}), \mathrm{pH}-8(5.236 \mathrm{U} / \mathrm{ml})$ and $\mathrm{pH}-9$ (4.550U/ml). Next to bacterial consortium, maximum azoreductase activity was observed in Bacillus odyssey, Bacillusthuringiensis, Bacillus subtilis, Bacillus cereus, Alcaligenessp. And Nocardiopsis alba. The effect of temperature stability on azoreductase activity was investigated. The azoreductase activity was assessed at $30^{\circ} \mathrm{C}, 40^{\circ} \mathrm{C}, 50^{\circ} \mathrm{C}, 60^{\circ} \mathrm{C}$ and $70^{\circ} \mathrm{C}$. Maximum azoreductase activity was recorded by the bacterial consortium at $40^{\circ} \mathrm{C}(9.431 \mathrm{U} / \mathrm{ml})$ followed by $30^{\circ} \mathrm{C}(8.896 \mathrm{U} / \mathrm{ml}), 50^{\circ} \mathrm{C}(8.621 \mathrm{U} / \mathrm{ml}), 60^{\circ} \mathrm{C}(7.772 \mathrm{U} / \mathrm{ml})$ and $70^{\circ} \mathrm{C}(7.623 \mathrm{U} / \mathrm{ml})$. Next to bacterial consortium, maximum azoreductase activity was observed in Bacillus odyssey, Bacillus thuringiensis, Bacillussubtilis, Bacillus cereus, Alcaligenessp. and Nocardiopsisalba. Temperature optima for azoreductases from Bacillus subtilis reported in the literature range from 40 to $45^{\circ} \mathrm{C}$. Similarly, in this work, the azoreductase from Bacillus cereus showed a temperature optimum at $40^{\circ} \mathrm{C}$ with a $\mathrm{pH}$ optimum at $\mathrm{pH} 7$ (Saranraj P et al., 2014).

The results obtained from present investigation revealed the ability of Cosmarium sp. in biodegradation of MG. To estimate the optimum biomass of algae, removal of 10 $\mathrm{mg} / \mathrm{l} \mathrm{MG}$ was monitored by different algal biomass (0$7.5 \times 10^{6}$ cell $\left./ \mathrm{ml}\right)$ during various contact times. As results showed, dye removal significantly increased along with an increase in the biomass concentration until it reached the value of $87.1 \%$ for the biomass of $4.5 \times 10^{6} \mathrm{cell} / \mathrm{ml}$, followed by an insignificant dye removal for increase of algal biomass. This seems to indicate that the biomass of $4.5 \times 10^{6} \mathrm{cell} / \mathrm{ml}$ would be the optimal biomass in our study. Removal of dye was examined for different concentration of dye solution by $4.5 \times 10^{6}$ cell $/ \mathrm{ml}$ of algal biomass (Daneshwar N et al., 2005).

In this study, Chlorella pyrenoidosa was used for the dye degradation and the enzymatic study were done in two forms and found the highest enzymatic activity in Intracellular form than the extracellular form. In this way, the Enzymatic processes for treatment of dyes are promising method which do not involve the use of chemicals and extremely safer to environment.

\section{Conclusion}

Removal of color from effluents remains a challenge to the environment, though a number of physico-chemical processes have been standardized. These azodyes comprised of chemicals or synthetic compounds severely affect the biotic life of the environment indirectly. Biodegradation of synthetic dyes using algae is becoming a potential approach for the treatment of dye wastewaters. To develop a low cost and low-technological bioprocess for the treatment of dye waste waters, the enzymes secreted from algae which can be isolated in various forms proved to be a good source involving no chemical treatment. The biodegradation abilities of algae can be improved gradually by exposing them to higher concentrations of azodyes. Algae decolorisation and degradation is a simple efficient method for treating and separating the water from dyes.

\section{References}

[1] Abdullah T. Al-Fawwaz, Mufida Abdullah, "Decolorization of Methylene Blue and Malachite Green by Immobilized Desmodesmus sp. Isolated from North Jordan", Interational Journal of Environmental Science and Development, 7(2), 2016. 


\section{International Journal of Science and Research (IJSR) \\ ISSN (Online): 2319-7064}

Index Copernicus Value (2013): 6.14 | Impact Factor (2015): 6.391

[2] Ambatkar Mugdha, Mukundan Usha, "Enzymatic Treatment of Wastewater Containing Dyestuffs Using Different Delivery Systems", Scientific Reviews and Chemical Communications, 2(1), 31-40, 2012.

[3] Daneshvar N., Ayazloo M., Khataee A. R., Pourhassan M., "Biodegradation of the Textile Dye Malachite Green by Microalgae Cosmarium sp.", Archieve of SID, 2005.

[4] Hala Yassin El-Kassas', Laila Abdelfattah Mohamed, "Bioremediation of the textile waste effluent by Chlorella vulgaris”, Egyptian Journal of Aquatic Research, 40(3), 301-308, , 2014.

[5] Hanan Hafez Omar, "Algal Decolorization and Degradation of Monoazo and Diazo Dyes", Pakistan Journal of Biological Science, 11, 1310-1316, 2008.

[6] Karthik V., Saravanan K., Teema Thomas, Devi M. Review on microbial decolourisation of textile dyes, J. Chem. Pharm. Sci., 2009, 7(4).

[7] Lavanya C., Rajesh Dhankar, Sunil Chhikara, Saritasheoran, "Degradation of Toxic Dyes: A Review", International Journal of Current Microbiology and Applied Sciences, 3(6), 189-199, 2014.

[8] Mahalakshmi S., Lakshmi D., Menaga U., "Biodegradation of Different Concentration of dye (Congo red dye) by using Green and Blue Green Algae", International Journal of Environmental Research, 9(2), 735-744, 2015.

[9] Ponraj M., Gokila K., Vasudeo Zambare, "Bacterial Decolorization of Textile Dye- Orange 3R", International Journal of Advanced Biotechnology Research, 2(1), 168-177, 2011.

[10] Saranraj P., Stella D., Sivasakthivelan P., "Separation, purification and characterization of dye degrading enzyme azoreductase from bacterial isolates", Central European Journal of Experimental Biology, 3(2), 1925, 2014.

[11] Sudha M., Saranya A., Selvakumar G., Sivakumar N., "Microbial degradation of Azo Dyes: A review", International Journal of Current Microbiology and Applied Sciences, 3(2), 670-690, 2014 